\title{
Congenital adrenal hyperplasia: clinical symptoms and diagnostic methods
}

\author{
Rafał Podgórski1, ${ }^{1}$, David Aebisher ${ }^{3}$, Monika Stompor ${ }^{1,2}$, Dominika Podgórska ${ }^{4}$ and \\ Artur Mazur 5
}

'Centre for Innovative Research in Medical and Natural Sciences, University of Rzeszów, Rzeszów, Poland; ${ }^{2}$ Department of Biochemistry, Faculty of Medicine, University of Rzeszów, Rzeszów, Poland; '3Department of Human Immunology, Faculty of Medicine, University of Rzeszów, Rzeszów, Poland; ${ }^{4}$ Department of Rheumatology, Clinical Provincial Hospital No. II in Rzeszów, Rzeszów, Poland; ${ }^{5}$ Department of Pediatrics, Pediatric Endocrinology and Diabetes, Medical Faculty, University of Rzeszów, Rzeszów, Poland

The aim of this paper is a straightforward presentation of the steroidogenesis process and the most common type of congenital adrenal hyperplasia (CAH) - 21-hydroxylase deficiency - as well as the analytical diagnostic methods that are used to recognize this disease. CAH is a family of common autosomal recessive disorders characterized by impaired adrenal cortisol biosynthesis with associated androgen excess due to a deficiency of one or more enzymes in the steroidogenesis process within the adrenal cortex. The most common and prototypical example of the $\mathrm{CAH}$ disorders group (90-95\%) is caused by 21-hydroxylase deficiency. Less frequent types of CAH are $11 \beta$-hydroxylase deficiency (up to $8 \%$ of cases), 17a-hydroxylase deficiency, $3 \beta$-hydroxysteroid dehydrogenase deficiency, P450 oxidoreductase deficiency and StAR deficiencies. In the 21-hydroxylase and $11 \beta$-hydroxylase deficiency, only adrenal steroidogenesis is affected, whereas a defect in $3 \beta$-hydroxysteroid dehydrogenase or 17a-hydroxylase also involves gonadal steroid biosynthesis. Many countries have introduced newborn screening programs based on immunoassays measuring 17-hydroxyprogesterone from blood spots used for other neonatal screening tests which enable faster diagnosis and treatment of $\mathrm{CAH}$. Currently, chromatographic techniques coupled with mass spectrometry are gaining popularity due to an increase in the reliability of the test results.

Key words: Congenital Adrenal Hyperplasia, $\mathrm{CAH}$, steroidogenesis, 21-hydroxylase deficiency

Received: 20 October, 2017; revised: 29 December, 2017; accepted: 02 February, 2018; available on-line: 15 March, 2018

\section{e-mail: rpodgorski@ur.edu.pl}

Abbreviations: 17-OHP, 17-hydroxyprogesterone; 21-OHD, 21-hydroxylase deficiency; ACTH, Adrenocorticotropic hormone; $\mathrm{CAH}$ Congenital adrenal hyperplasia; $\mathrm{CRH}$, Corticotrophin hormone; CYP450, Cytochrome P450; DHEA, Dehydroepiandrosterone; GC-MS, Gas chromatography mass spectrometry; LC-MS/MS, Liquid chromatography tandem-mass spectrometry; HSD $11 \beta$, $11 \beta$-hydroxysteroid dehydrogenase; HSD17 $\beta, 17 \beta$-hydroxysteroid dehydrogenase; HSD3 $\beta 2$, 3 $\beta$-hydroxysteroid dehydrogenase; HSDs, Steroid dehydrogenase; NBS, Newborn screening; NC CAH, Nonclassical congenital adrenal hyperplasia; StAR, Steroidogenic acute regulatory protein; SV CAH, Simple virilizing congenital adrenal hyperplasia; SW CÁH, Salt-wasting congenital adrenal hyperplasia

\section{INTRODUCTION}

The first case of a patient with congenital adrenal hyperplasia $(\mathrm{CAH})$ was described by the Italian physician
Luigi De Crecchio in 1865. He released the autopsy report of a 44-year-old man who died from an apparent Addisonian crisis that had external male genitals and internal female reproductive organs and significantly enlarged adrenal glands (New, 2011; Delle Piane et al., 2015). After that, at least five different types of congenital adrenal hyperplasia associated with impaired function of enzymes involved in the synthesis of steroids have been reported. As mentioned above, 21-hydroxylase deficiency (21-OHD) is the most common type of CAH; less frequent are $11 \beta$-hydroxylase deficiency, $17 \alpha$-hydroxylase deficiency, P450 oxidoreductase deficiency and lipoid congenital adrenal hyperplasia (StAR deficiency) (Krone et al., 2007; Kaur et al., 2016) (Table 1). In all types of $\mathrm{CAH}$, the most important result of dysfunction of one of the intermediate steroidogenesis stages is low cortisol production which is the major glucocorticoid hormone. Low blood cortisol levels stimulate secretion of corticotrophin $(\mathrm{CRH})$ and adrenocorticotropic hormone $(\mathrm{ACTH})$ by the hypothalamus and pituitary, which indirectly (CRH) and directly (ACTH) induces secretory function of the adrenal cortex. Constantly elevated ACTH levels lead to adrenal hyperplasia, accumulation of steroid hormones precursors, and hyperandrogenism (Pang et al., 1993; Speiser et al., 2010).

\section{STEROIDOGENESIS}

\section{Synthesis of steroid hormones}

Steroid hormones are produced in the adrenal cortex (glucocorticoids, mineralocorticoids), testis (strong androgens), ovary (estrogens), and some peripheral tissues (adipose tissue, the brain). One of the main organs, where the synthesis of steroid hormones occurs, is the adrenal cortex, which consists of 3 layers:

- zona glomerulosa - outwardly located, representing $15 \%$ of the organ weight; within it, the synthesis of the most important mineralocorticoid - aldosterone - takes place

- zona fasciculata - represents $75 \%$ of the cortex weight, situated between the zona glomerulosa and reticularis, and responsible for producing glucocorticoids such as cortisol

- zona reticularis - represents $10 \%$ of the gland weight and is located closest to the adrenal medulla; within it, there is the synthesis of adrenal androgens like dehydroepiandrosterone (DHEA) (Pang et al., 1987; Yau et al., 2016b). 
Table 1. The most common steroidogenesis enzyme deficiencies inducing CAH.

\begin{tabular}{|c|c|c|c|c|c|c|c|}
\hline Enzyme deficiency & $\mathbf{F}$ & Substrate & Product & A & M & G & References \\
\hline 21-Hydroxylase deficiency & $90-95 \%$ & $\begin{array}{l}\text { Progesterone, } \\
\text { 17-OH-progesterone }\end{array}$ & $\begin{array}{l}\text { Deoxycorticosterone } \\
11 \text {-deoxycortisol }\end{array}$ & $\uparrow$ & $\downarrow$ & $\downarrow$ & $\begin{array}{l}\text { (Parsa \& New, } \\
\text { 2017) }\end{array}$ \\
\hline $11 \beta$-Hydroxylase deficiency & $0.2-8 \%$ & Deoxycorticosterone & Corticosterone & $\uparrow$ & $\uparrow$ & $\downarrow$ & $\begin{array}{l}\text { (Bulsari \& Fal- } \\
\text { hammar, 2017) }\end{array}$ \\
\hline 17a-Hydroxylase deficiency & rare & $\begin{array}{l}\text { Pregnenolone, } \\
\text { Progesterone }\end{array}$ & $\begin{array}{l}\text { 17-OH- pregnenolon, } \\
\text { 17-OH-progesteron }\end{array}$ & $\downarrow$ & $\uparrow$ & $\downarrow$ & (Miller 2012) \\
\hline $\begin{array}{l}\text { 3ß-Hydroxysteroid } \\
\text { dehydrogenase } \\
\text { deficiency }\end{array}$ & $<5 \%$ & $\begin{array}{l}\text { Pregnenolone, } \\
\text { 17-OH-pregnenolone, } \\
\text { DHEA }\end{array}$ & $\begin{array}{l}\text { Progesterone, } \\
\text { 17-OH-progesteron, } \\
\text { Androstendione }\end{array}$ & $\downarrow$ & $\downarrow$ & $\downarrow$ & $\begin{array}{l}\text { (Benkert et al., } \\
\text { 2015) }\end{array}$ \\
\hline $\begin{array}{l}\text { P450 oxidoreductase } \\
\text { deficiency }\end{array}$ & rare & $\begin{array}{l}\text { Pregnenolone, } \\
\text { Progesterone }\end{array}$ & $\begin{array}{l}\text { DHEA } \\
\text { 11-deoxycortisol }\end{array}$ & $\begin{array}{l}\text { Antenatal } \uparrow \\
\text { Postnatal } \downarrow\end{array}$ & $\leftrightarrow$ & $\downarrow$ & (Arlt et al., 2004) \\
\hline StAR deficiency & rare & Cholesterol & $\begin{array}{l}\text { Impaired transport of } \\
\text { cholesterol to the inner } \\
\text { side of the mitochondrial } \\
\text { membrane }\end{array}$ & $\downarrow$ & $\downarrow$ & $\downarrow$ & $\begin{array}{l}\text { (Miller \& Au- } \\
\text { chus, 2011) }\end{array}$ \\
\hline
\end{tabular}

Abbreviations: F - frequency, A - androgens, $\mathbf{M}$ - mineralocorticoids, G - glucocorticoids

In the process of steroidogenesis (Fig. 1), two types of enzymes can be distinguished:

\section{I - cytochrome P450 (CYP450)}

\section{II - steroid dehydrogenases (HSDs)}

Cytochrome P450 is a generic term for a large group of oxidative enzymes that are composed of about 500 amino acids and contain a single heme group. When in reduced form and complexed with carbon monoxide, the enzyme absorbs electromagnetic radiation at $450 \mathrm{~nm}$ and for this reason, is termed P450 (Gonzalez, 1988). The human genome includes genes for 57 cytochrome P450 enzymes and they are named CYP genes (Lander et al., 2001; Venter et al., 2001). Most of the CYP450 is localized in the endoplasmic reticulum of liver cells, where nonspecific oxidation of endogenous toxins, drugs and xenobiotics takes place (Gonzalez, 1988).

In the process of steroidogenesis, 7 distinct cytochrome P450 enzymes are involved (Table 2). All P450 oxidases operate in correlation with the mitochondrial electron transfer system.

Electrons from NADPH (reduced form of nicotinamide adenine dinucleotide phosphate) are transferred to CYP450 and reduce it:

Type I P450 - reduced by adrenodoxin (a small iron-sulfur protein) with the participation of flavoenzyme - adrenodoxin reductase. Type I enzymes include P450scc, P450c11ß, P450c11AS, and other enzymes involved in vitamin D and bile acid metabolism (Pang et al., 1987; Gonzalez, 1988; Lander et al., 2001; Venter et al., 2001; Miller, 2005).

Type II P450 - reduced with the involvement of a single 2-flavin protein termed P450 oxidoreductase (POR). Type II P450 enzymes include steroidogenic P450c17, P450c21 and P450aro (Miller, 2005; Ghayee \& Auchus, 2007; Miller \& Auchus, 2011).

Type I enzymes reside in the mitochondria, while type II reside in the smooth endoplasmic reticulum (Nelson et al., 1993).

Hydroxysteroid dehydrogenases and reductases are an enzyme group with molecular weights between 35$45 \mathrm{kD}$ that occur in one or more isoforms (each is en- coded by a distinct gene). They lack a heme moiety and require nicotinamide adenine dinucleotide (phosphates) $\left(\mathrm{NADH} / \mathrm{NAD}^{+}\right.$or $\left.\mathrm{NADPH} / \mathrm{NADP}^{+}\right)$for their activity. Generally, HSDs catalyze redox reactions, regulate the ratio of hydroxy- and ketosteroids in cells and in plasma. Oxidative HSDs use $\mathrm{NAD}^{+}$as a cofactor and convert hydroxysteroids to ketosteroids, while reductive HSDs use NADPH to reduce ketosteroids to hydroxysteroids. Steroidogenic HSDs include $3 \alpha$ - and $3 \beta$-hydroxysteroid dehydrogenase (HSD3 $\beta 2$ ), two 11 $\beta$ - hydroxysteroid dehydrogenases (HSD11 1 1 and HSD11 32 ) and a series of $17 \beta$-hydroxysteroid dehydrogenases (HSD17 $\beta$ ) (Penning, 1997; Agarwal \& Auchus, 2005; Ghayee \& Auchus, 2007).

\section{Regulation of hormone secretion}

The secretion of adrenal cortex hormones is always correlated with the de novo synthesis of steroids because unlike other secreting glands (e.g. pancreas), adrenal glands tend not to accumulate hormones stocks. This entails the necessity of an immediate response to the demand and production of the new hormones.

As shown in Fig. 1, the synthesis of steroid hormones is a multistep process that is regulated by adrenocorticotropic hormone (ACTH) through:

- trophic action (as a result of long-term stimulation) - physiological growth of adrenal cells (Ferguson, 1963; Ney et al., 1967)

- cell mediators (cAMP) - they stimulate the expression of genes encoding enzymes involved in steroidogenesis (mainly CYP11A1 gene encoding P450 scc) (Mesiano et al., 1991)

- increasing the production and activation of StAR (steroidogenic acute regulatory protein) that is responsible for the transfer of free cholesterol from cytosol or outer mitochondrial membrane to the inner mitochondrial membrane. As a result, cholesterol and $\mathrm{P} 450_{\text {scc }}$ are brought into contact to initiate biosynthesis. This is the most important stage of the regulating process which limits the speed of the whole steroid biosynthesis (Pon et al., 1986; Arakane et al., 1997). 


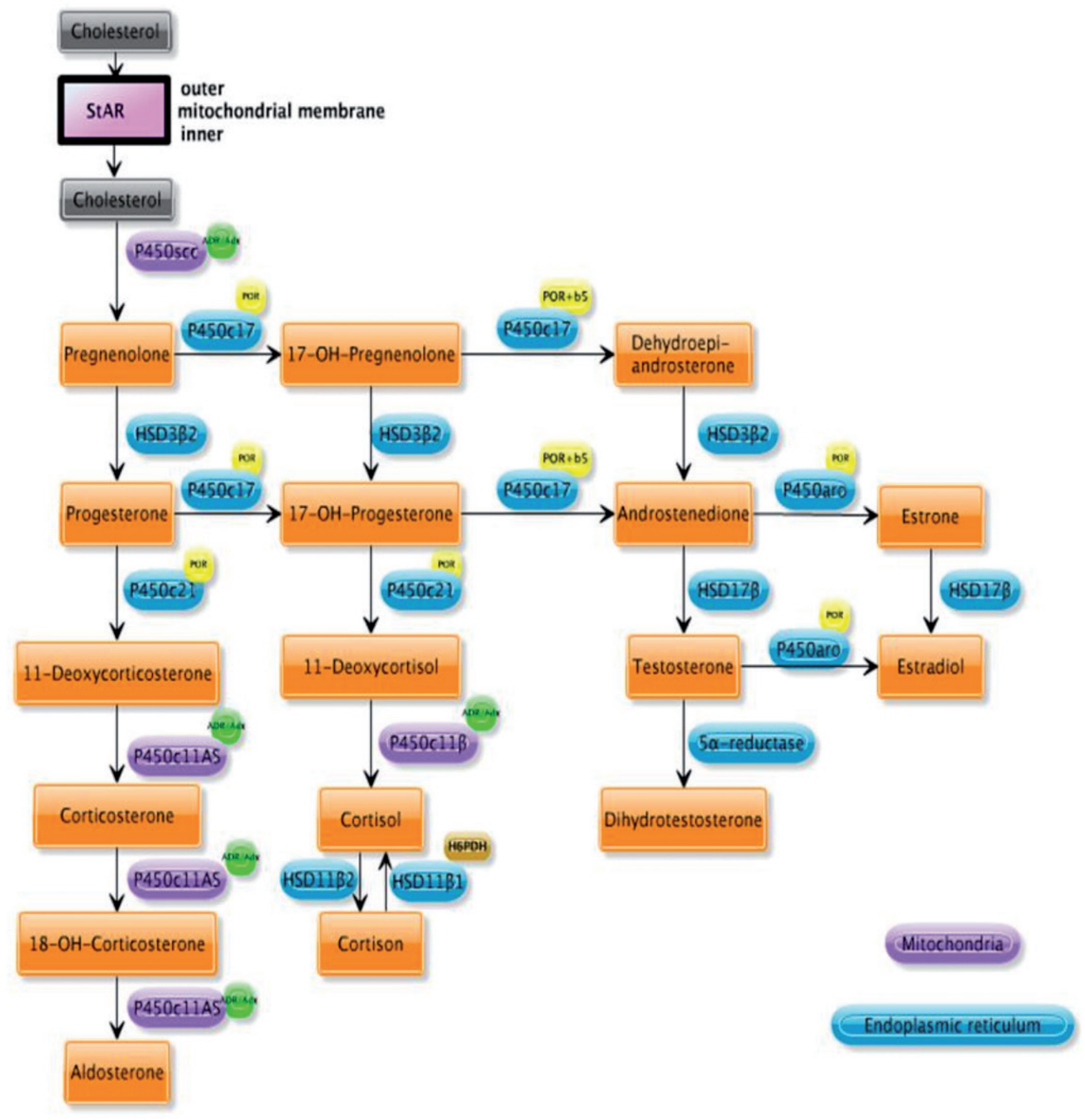

Figure 1. Pathway of human steroid biosynthesis (Krone et al., 2010)

Abbreviations: ADR, adrenodoxin reductase; Adx, adrenodoxin; POR, P450 oxidoreductase; $\boldsymbol{b}_{5}$, cytochrome $\boldsymbol{b}_{5}$; H6PDH, hexose-6-phosphatedehydrogenase (cofactor); $\mathrm{OH}$, hydroxyl; $\mathrm{P}_{450}{ }_{\text {scc, }} \mathrm{P} 450$-side-chain-cleavage enzyme; HSD3 32 , hydroxysteroid dehydrogenase type 2; P450c17, 17-a hydroxylase; P450c21, 21-hydroxylase; P450c11 $\beta, 11 \beta$-hydroxylase; P450c11AS, aldosterone synthase; HSD17 $\beta$, $17 \beta$-hydroxysteroid dehydrogenase; CYP19A1, P450aro, P450 aromatase.

\section{CONGENITAL ADRENAL HYPERPLASIA (CAH)}

As seen in Fig. 1, 21-hydroxylase deficiency impairs the conversion of 17-hydroxyprogesterone (17-OHP) to 11-deoxycortisol and progesterone to 11-deoxycorticosterone, which are both the key precursors in the synthesis pathway of cortisol and aldosterone. Accumulation of excessive 17-hydroxyprogesterone (before this point biosynthesis of steroids functions normally) amplifies the pathway of androgen production, wherein P450c21 is not involved. Depending on the severity of mutations and the loss of functionality of 21-hydroxylase, congenital adrenal hyperplasia can take two clinical forms: a severe-classical and a mild non-classical (Trapp et al., 2011).

\section{Classic Congenital Adrenal Hyperplasia}

The classical form of CAH affects between 1:10000 and 1:20000 infants of the Caucasian race (Reisch \& Kuhnle, 2014). However, there are communities where this frequency is much higher. For instance, for Yupikspeaking Eskimos, a small and closed ethnic group, the incidence was found to be 1:282 and in Brazilian patients 1:7 500 (Pang et al., 1982, 1993). In contrast, considerably lower incidences were found in African-Americans and 
Table 2. Isoenzymes of cytochrome P450 involved in adrenal steroid hormone synthesis (Van der Kamp et al., 2001; Miller 2005; Miller \& Auchus, 2011)

\begin{tabular}{|c|c|c|c|c|c|}
\hline Enzyme & Symbol & Activity & Cellular localization & Adrenal localization & Gen \\
\hline $\begin{array}{l}\text { Cholesterol side-cha- } \\
\text { in cleavage enzyme }\end{array}$ & $\begin{array}{l}\text { P450scc (formerly } \\
\text { 20,22-desmolase) }\end{array}$ & $\begin{array}{l}\text { 20a-hydroxylase } \\
\text { 22-hydroxylase, } \\
\text { 20,22-lyase }\end{array}$ & Mitochondria & Each & CYP11A1 \\
\hline $\begin{array}{l}\text { Steroid } \\
11 \beta \text {-hydroxylase }\end{array}$ & $P 450 c 11 \beta$ & Steroid $11 \beta$-hydroxylase & Mitochondria & Fasciculata & CYP11B1 \\
\hline Aldosterone synthase & P450c11AS & $\begin{array}{l}\text { 11-hydroxylase, } \\
\text { 18-hydroxylase, } \\
\text { 18-hydroxydehydrogenase }\end{array}$ & Mitochondria & Glomerulosa & CYP11B2 \\
\hline $\begin{array}{l}\text { Steroid } \\
\text { 17a-hydroxylase }\end{array}$ & P450c17 & $\begin{array}{l}\text { 17-hydroxylase } \\
\text { 17,20-lyase }\end{array}$ & $\begin{array}{l}\text { Endoplasmic reticu- } \\
\text { lum }\end{array}$ & Fasciculata Reticularis & CYP17A1 \\
\hline $\begin{array}{l}\text { Steroid 21-hydro- } \\
\text { xylase }\end{array}$ & P450c21 & 21-hydroxylase & $\begin{array}{l}\text { Endoplasmic reticu- } \\
\text { lum }\end{array}$ & Each & CYP21A2 \\
\hline P450 oxidoreductase & POR & $\begin{array}{l}\text { Transfer electrons from } \\
\text { NADPH to cytochrome } \\
\text { P450 }\end{array}$ & $\begin{array}{l}\text { Endoplasmic reticu- } \\
\text { lum }\end{array}$ & Each & POR \\
\hline $\begin{array}{l}\text { P450 aromatase or } \\
\text { estrogen synthetase }\end{array}$ & P450aro & $\begin{array}{l}\text { Aromatization of andro- } \\
\text { gens into estrogens }\end{array}$ & $\begin{array}{l}\text { Endoplasmic reticu- } \\
\text { lum }\end{array}$ & $\begin{array}{l}\text { Gonads (granulosa } \\
\text { cells) }\end{array}$ & CYP19A1 \\
\hline
\end{tabular}

Native Americans - 1:42000 (Merke \& Bornstein, 2005; Therrell \& Adams, 2007).

The classical form of CAH occurs in two phenotype forms: simple virilizing (SV) and salt-wasting (SW).

\section{Salt-wasting Congenital Adrenal Hyperplasia}

The salt-wasting congenital adrenal hyperplasia (SW) is the most severe type and accounts for $75 \%$ of all cases of classical CAH. SW appears when mutations in the gene CYP21A2 are so extensive that 21-hydroxylase loses nearly all its enzymatic activity $(<2 \%)$ (Parsa \& New, 2017). This leads to a life threatening impairment of the synthesis of not only cortisol but aldosterone as well. Aldosterone is responsible for the body's homeostatic sodium regulation. If left untreated, low levels of aldosterone leads to hypovolemia, hyponatremia, hyperkaliemia, hyperreninemia, development disorders, weight loss, convulsions and finally death of a newborn during the 1-4 weeks after birth. Rapid diagnosis is crucial to increase the chance of the child survival. Subsequently, in many countries (for the first time in USA, in 1977), a national program of newborn screening for 21-OHD has been introduced (Pang et al., 1977; Van der Kamp et al., 2001).

Affected male newborns without signs of ambiguous genitalia, are particularly prone to the occurrence of associated salt adrenal crisis and death, a few days after discharge from the hospital. A similar situation occurres in adult patients that are treated with mineralocorticoid and abruptly stop the therapy. In boys, the main source of testosterone are testicles, not adrenal glands. For that reason, at the time of birth, they do not display ambiguous genitalia. The only external symptom pointing to irregularities is genital hyperpigmentation, and sometimes penis enlargement (Merke \& Bornstein, 2005). Female infants with classic CAH typically have ambiguous genitalia at birth due to intrauterine exposure to high androgen concentrations. Characteristic symptoms include an enlarged clitoris, rugose and partly fused labia majora, a common urogenital sinus in place of a separate urethra and vagina and even development of the male urethra. The internal female organs, the uterus, fallopian tubes, and ovaries are normal; fertility usually is preserved, but there is no development of the Wolffian duct (Speiser \& White, 2003a). The occurrence of such obvious anomalies results in proper diagnosis and immediate treatment (Yau et al., 2016b). The treatment is based on replacement therapy with glucocorticoids and mineralocorticoids (connected with periodic monitoring of renin and aldosterone levels).

Hydrocortisone is the glucocorticoid of choice during childhood (Pang et al., 1977; Clayton et al., 2002; Speiser \& White, 2003b), whereas adults usually take longer-acting medicines like dexamethasone and prednisone, which can induce growth suppression in children. Mineralocorticoid replacement is achieved with fludrocortisone, and the dose is adjusted to maintain plasma renin activity in the mid-normal range (Rivkees \& Crawford, 2000; Clayton et al., 2002; Punthakee et al., 2003).

If left untreated or improperly treated, postnatal hyperandrogenism causes progressive virilization, including premature development of pubic and axillary hair, acne, advanced skeletal age and somatic development, and centrally induced precocious puberty in boys and girls (Quintos et al., 2001; New, 2003; Demirci \& Witchel, 2008; Lin-Su et al., 2011). One of the effects of CAHinduced precocious puberty is closing of the epiphyseal cartilage of bone during normal linear growth, which leads to the reduction in the patients' height, which is below the population mean.

Proper treatment affords the opportunity to improve the condition of patients with SW CAH, however, it does not change the need for glucocorticoid administration (Stoner et al., 1986; Eugster et al., 2001).

Simple virilizing Congenital Adrenal Hyperplasia

A small increase (1-2\%) of the enzymatic activity of 21-hydroxylase, compared to SW CAH leads to the de- 
velopment of SV CAH, which is responsible for the other $25 \%$ of classic CAH cases. Similarly to SW CAH, an accumulation of adrenal steroid precursors causes overproduction of androgens, which results in development of ambiguous genitalia of a various degree in girls. Aldosterone production is sufficient to prevent the onset of salt loss and adrenal crisis, so mineralocorticoids replacement therapy is not necessary (Parsa \& New, 2017). Ambiguous genitalia thought to be caused by SW CAH are often finally diagnosed as SV CAH; regardless, patients are treated with both mineralocorticoids and glucocorticoids at the onset to prevent adrenal crisis. It should be noted that boys, who have not undergone screening tests, are often diagnosed with a delay of several years, after the manifestation of long-term hyperandrogenism symptoms.

\section{Non-classic Congenital Adrenal Hyperplasia}

Non-classical (NC CAH) is one of the most common autosomal recessive genetic disorders. It occurs when the enzymatic activity of 21-hydroxylase is impaired to a lesser extent (20-50\% of the normal enzyme function). Cortisol and aldosterone levels are sufficient to sustain vital functions, hence hormone replacement therapy is not needed. However, there is no inhibition of ACTH secretion levels since cortisol levels are still too low and adrenal hyperplasia and hyperandrogenism eventually occur. NC CAH was diagnosed and described first in 1957 in a 26-year-old married woman who was regularly menstruating with properly developed genitalia, but with signs of hirsutism and acne (Decourt et al., 1957; Speiser, 2009). At the time of birth, children have normal genitalia, and the level of 17-OH-progesterone is often normal unless a blood sample is collected in the early morning (i.e., before $8 \mathrm{AM}$ ). Additionally, for reasons that are as yet unclear, 17-hydroxyprogesterone levels may not be elevated in newborns with CAH (Azziz et al., 1999). A diagnosis is often made after many years, mainly accidentally, during investigations of other diseases (Kohn et al., 1982; Falhammar \& Nordenström, 2015). According to the original clinical definition, the first symptoms should occur after 60 months of age. In a multicenter collaborative study on 220 women with NC CAH, only $11 \%$ were diagnosed before 10 years of age, while the majority $(80 \%)$ were diagnosed between 10 and 40 years of age. Symptoms in children that indicate NC CAH are premature pubic hair, precocious puberty, acne, accelerated growth (however, final height is reduced), and advanced bone age (Temeck et al., 1987; Ostlere et al., 1998; Dacou-Voutetakis \& Dracopoulou, 1999; Kashimada et al., 2008; Knowles et al., 2014; Voutilainen \& Jääskeläinen, 2015). In $5-10 \%$ of all cases of premature pubic hair, patients are suffering from NC CAH (Balducci et al., 1994; Dacou-Voutetakis \& Dracopoulou, 1999). The most common symptoms for affected adults include hirsutism (60-78\%), menstrual cycle disorders (55\%), acne $(33 \%)$ and decreased fertility (12\%) (Moran et al., 2000). These signs, as the results of elevated androgen levels, are more pronounced in women. In men, the disease is often asymptomatic or only with visible acne and/or a reduction of fertility (Falhammar \& Nordenström, 2015).

Treatment is guaranteed only if the patient is symptomatic and desires treatment. Small dosages of glucocorticoids are required to control symptoms of androgen excess. Sometimes, unfortunately, this is not easy to achieve and higher doses are necessary in many cases resulting in overtreatment with an increased risk of longterm side effects (Falhammar et al., 2007; Falhammar et al., 2013). For this reason, new generations of drugs displaying extended hydrocortisone release will be preferred in CAH therapy in the future (Verma et al., 2010).

\section{DIAGNOSIS}

The diagnosis of classical CAH may be based on a careful examination of the external appearance of newborns (mainly genitals), so physicians should be encouraged in this regard. It should be remembered that the symptoms of ambiguous reproductive organs in a child does not determine unequivocally the occurrence of congenital adrenal hyperplasia. The cause of such symptoms might be exposure of the fetus in the womb to elevated androgens levels, which may occur as a result of various factors (e.g. mother's illness). Before the final diagnosis, detailed studies should be carried out to determine the real cause of the disorder (Demirci \& Witchel, 2008).

In countries where CAH screening tests have been introduced, diagnosis is based on the determination of 17-hydroxyprogesterone plasma levels, a precursor for a dysfunctional enzyme 21-hydroxylase (Barnes \& Atherden, 1972). 17-OHP level is elevated at birth, quickly decreases in healthy newborns, but persists in affected children (Marumudi et al., 2013). The 17-OHP level is measured in filter paper blood spots obtained by heel puncture preferably between 2 and 4 days after birth, along with other screening assays. Sample collection after 5-7 days of birth reduces the benefit of screening, because the adrenal crisis associated with loss of salt may have already occurred (Van der Kamp et al., 2001). However, some reports indicate that an additional second newborn screening for congenital adrenal hyperplasia can identify about $30 \%$ of formerly unrecognized CAH cases (Therrell et al., 1998; Chan et al., 2013).

Medical societies in countries where NBS programs have not been implemented should strongly encourage national institutions and governments to introduce this screening test to their healthcare programs. Undoubtedly, screening markedly reduces the time required for the diagnosis of infants with $\mathrm{CAH}$. The main putative benefit of early diagnosis is reduced morbidity and mortality, particularly among babies with the salt-wasting form of this disease. Newborn screening for $\mathrm{CAH}$ has been shown to be cost-effective when its cost is compared with the lifetime tax contribution of a productive citizen; the direct cost analysis for one specimen is only $\$ 2.10$ (Pang et al., 1988; Chan et al., 2013).

Three assay techniques are utilized for initial screening: radio-immunoassay (USA), enzyme-linked immunosorbent assay (Japan), and time-resolved fluoro-immunoassay (Europe). These tests allow one to clearly detect SW CAH. SV CAH is less likely to be detected while $\mathrm{NC} \mathrm{CAH}$ is not recognized for the most part (slight increase of 17-OHP). It should be noted that a large number of false positives (approx. 0.5\%), as a result of crossreactivity of steroid conjugates and insufficient antibody specificity, is a cause of anxiety in parents (Gurian et al., 2006; Trapp et al., 2011). This risk increases in premature babies, sick and stressed children with low birth weight or term newborns tested earlier than $36 \mathrm{~h}$ after the delivery (Lee et al., 1989; Wong et al., 1992). On the other hand, glucocorticoid therapy during pregnancy can result in false negative results (King et al., 2001; Gatelais et al., 2004). A positive result should be confirmed by a second, more advanced analytical method such as high performance liquid chromatography tandem-mass spectrometry (LC-MS/MS) or gas chromatography mass 
spectrometry (GC-MS) (Shackleton, 1986; Monostori et al., 2015). Chromatographic methods allow simultaneous measurement of several analytes in the sample and determination of the precursor/product ratio (e.g. 17-OHP + deoxycortisol/cortisol). This significantly reduces the possibility of a false positive test result particularly in premature infants and neonates under stress. Despite the fact that chromatographic techniques provide more reliable results, they are still used as a second-tier test because they are more expensive, time-consuming, demand technical expertise and require specialized knowledge; currently, these factors prevent the widespread use of chromatography in the field of $\mathrm{CAH}$ diagnosis (Kao et al., 2001; White, 2009).

The gold standard for distinguishing 21-hydroxylase deficiency from other enzyme defects is the ACTH (cosyntropin) stimulation test, performed by injecting a bolus of cosyntropin and measuring baseline and stimulated (after 60 minutes) serum levels of 17-hydroxyprogesterone and often androstenedione as well. The level of target metabolites before stimulation does not differ from the norm, however, they increase significantly afterwards indicating the final diagnosis (New et al., 1983). Children showing clinical evidence of androgen excess like oily skin, premature pubic and axillary hair growth and rapid somatic growth should undergo morning baseline 17OHP testing. 17-OHP values $>200-1000 \mathrm{ng} / \mathrm{dl}$ should be followed with a stimulated cosyntropin test measuring levels of 17-OHP and androstenedione at baseline and at 60 minutes (Parsa \& New, 2017).

In order to diagnose patients with $\mathrm{NC} \mathrm{CAH,} \mathrm{which}$ present nonspecific symptoms of NCAH including hirsutism, irregular menses, chronic anovulation, acne, and infertility it is necessary to subject the patient to an ACTH stimulation test, which relies on the measurement of 17-OHP and androstenedione 60 minutes before and after administration of ACTH. The level of these metabolites before stimulation does not differ from the norm, however, they may increase significantly allowing diagnosis. Due to similar clinical features, it may be difficult to distinguish NC CAH patients from women suffering from polycystic ovary syndrome. The first group tends to have higher 17-OHP and progesterone concentrations than women in the second group, which demonstrate insulin resistance, obesity, polycystic ovary morphology, and elevated $\mathrm{LH} / \mathrm{FSH}$ ratios. Men with $\mathrm{NC} \mathrm{CAH}$ are typically identified through family studies (Witchel, 2017).

Other diagnostic procedures in patients affected by $\mathrm{CAH}$ can be broadened to include genetic tests that clearly confirm the nature of disorders (especially in patients with $\mathrm{NC} \mathrm{CAH}$ ) and determine the degree of mutation and disease severity. In most cases, phenotypic disease severity may be predicted from genotypic findings. This correlation can provide a significant guide for short- and long-term treatment of patients. Use of genetic testing is also helpful in prenatal counseling of mothers affected by NC CAH planning to have children. It should be noted that molecular genetic diagnosis is more complicated for 21-OHD than for many other monogenic disorders due to the high variability of the genomic region. Most CYP21A2 gene mutations encoding 21-hydroxylase arise from an exchange or conversion of genetic material at the time of meiotic recombination between CYP21A2 and inactive pseudogene CYP21A1P (98\% homologous with CYP21A2). Both are located on the short arm of chromosome 6 (6p21.3). Another $20 \%$ of CAH cases are caused by unequal crossing-over during meiosis, resulting in the deletion of a $30-\mathrm{kb}$ gene segment. The remaining part of the affected alleles con- sists of the spontaneous mutations not carried by either parent. To date, more than 300 CYP21A2 mutations have been discovered, and about 10 common mutations account for approximately $90 \%$ of cases (Bronstad et al., 2014; Falhammar et al., 2015; Choi et al., 2016). Genetic analysis of 1507 families, that had at least one member affected by $\mathrm{CAH}$ showed frequencies of this common allelic mutations as follows: V281L (23.9\%), I2G (22.9\%), $30-\mathrm{kb}$ deletion or genomic rearrangement/conversion fusing CYP21 with CYP21P (20.0\%), I172N (8.2\%), R356W (3.6\%), Q318X (3.5\%), P30L (2.6\%), and exon 6 cluster mutation (I236N, V237E, M239K) (2.1\%) (New et al., 2013).

It should also be mentioned that the possibility of a prenatal diagnosis of CAH exists. Performing chorionic villus sampling (9-11 week of pregnancy) or amniocentesis (15-20) followed by genetic testing enables early detection of 21-OHD and prescribed therapy before birth. In children with increased probability of $\mathrm{CAH}$ (family risk), treatment should be introduced before the 9th week of gestation (dexamethasone) which effectively lowers the excessive adrenal androgens preventing the masculinization of female external genitalia. The findings of a genetic test between 9-11 weeks of gestation determine further patient management. The treatment is discontinued when the fetus is male or an unaffected female. Otherwise, the treatment is continued to term in three divided doses starting as soon as pregnancy is confirmed and no later than 9 weeks after the last menstrual period with dexamethasone at a dose of $20 \mathrm{mg}$ / $\mathrm{kg} /$ day based on the maternal pre-pregnancy bodyweight (Carlson et al., 1999; New et al., 2001; Nimkarn \& New, 2009). The procedures of amniocentesis and chorionic villus sampling (CVS) are risky. Studies have shown that these invasive procedures cause $0.1 \%$ (amniocentesis) and $0.2 \%$ (CVS) of the fetal loss (Evans \& Wapner, 2005; Akolekar et al., 2015). Complications of CVS and amniocentesis include talipes (clubfoot), hemangioma, infection, amniotic fluid leakage, or limb reduction defects (seen in CVS) (Lo et al., 1998; Bauland et al., 2012). Due to this risk, noninvasive techniques were introduced in 2011 that are very promising for extraction of fetal cellfree DNA from maternal blood. The biggest advantage of this test is that it can be done in the 6th week of gestation, allowing early diagnosis, before the onset of genital organogenesis which begins at approximately 9 week with avoidance of unnecessary treatments (American College of Obstetricians and Gynecologists Committee on Genetics, 2012; Devers et al., 2013; Benn et al., 2013). New et al., have reported that target capture sequencing of a $6 \mathrm{Mb}$ genomic region flanking CYP21A2 facilitated noninvasive genotype analysis of fetus with $\mathrm{CAH}$ using relative haplotype dosage analysis. Further research have shown that haplotype-based approach has an accuracy of $96.41 \%$ for the inferred maternal alleles and an accuracy of $97.81 \%$ for the inferred paternal alleles (New et al., 2014; Ma et al., 2014; Ma et al., 2017)

Because the genotype can be correlated to the phenotype in $\mathrm{CAH}$, genetic counseling helps to make the decision on prenatal dexamethasone treatment to avoid genital ambiguity in affected female fetuses. Furthermore, postnatal complications of adrenal insufficiency can be avoided by initiation of glucocorticoid and mineralocorticoid replacement at birth, especially in male newborn. However, based on current American College of Obstetricians and Gynecologist's guidelines which states that "Cell free fetal DNA does not replace the accuracy and diagnostic precision of prenatal diagnosis with CVS or amniocentesis, which remain an option for women," 
noninvasive prenatal diagnosis has not yet been established as a standard of care (Yau et al., 2016a).

\section{CONCLUSIONS}

$\mathrm{CAH}$ is a widespread autosomal recessive genetic disorder that can appear in childhood, adolescence or adulthood. Early diagnosis of SW CAH is a key factor in saving a newborn's life, and an early diagnosis of $\mathrm{NC} \mathrm{CAH}$ can significantly improve the quality of life and reduce the severity of ailments. The typical nonspecific symptoms of hirsutism, oligomenorrhea, infertility, acne, and premature pubic hair often leads to improper recognition of $\mathrm{NC}$ CAH. The 17-OHP level measurement is used in screening tests and in the diagnosis of 21-OHD. More sensitive and selective analytical techniques such as LC-MS/MS or GC-MS allow targeted steroid hormone analysis and are used to confirm the results. Due to high variability in 17-OHP levels among the patients, the identification of mutations within CYP21A2 is important to recognize the degree of mutation and the severity of the disease. Molecular genetic analysis enables confirmation of the diagnosis, providing genetic counseling and predicting treatment progress. The therapy should be individualized, adjusted and tailored to minimize the symptoms during the achievement of normal sexual development, fertility, height and generally a better quality of life (Speiser et al., 1992; Wedell et al., 1994; Krone et al., 2000; Witchel 2010).

\section{REFEREONCES}

Agarwal AK, Auchus RJ (2005) Minireview: cellular redox state regulates hydroxysteroid dehydrogenase activity and intracellular hormone potency. Endocrinology 146: 2531-2538. doi: 10.1210/en.20050061

Akolekar R, Beta J, Picciarelli G, Ogilvie C, D’Antonio F (2015) Procedure-related risk of miscarriage following amniocentesis and chorionic villus sampling: a systematic review and meta-analysis. Ultrasound Obstet Gynecol Off J Int Soc Ultrasound Obstet Gynecol 45: 16-26. doi: $10.1002 /$ uog. 14636

American College of Obstetricians and Gynecologists Committee on Genetics (2012) Committee Opinion No. 545: Noninvasive prenatal testing for fetal aneuploidy. Obstet Gynecol 120: 1532-1534. doi: 10.1097/01.AOG.0000423819.85283.f4

Arakane F, King SR, Du Y, Kallen CB, Walsh LP, Watari H, Stocco DM, Strauss JF (1997) Phosphorylation of steroidogenic acute regulatory protein (StAR) modulates its steroidogenic activity. $J$ Biol Chem 272: 32656-32662

Arlt W, Walker EA, Draper N, Ivison HE, Ride JP, Hammer F, Chalder SM, Borucka-Mankiewicz M, Hauffa BP, Malunowicz EM, Stewart PM, Shackleton CH (2004) Congenital adrenal hyperplasia caused by mutant P450 oxidoreductase and human androgen synthesis: analytical study. The Lancet 363: 2128-2135. doi: 10.1016/ S0140-6736(04)16503-3

Azziz R, Hincapie LA, Knochenhauer ES, Dewailly D, Fox L, Boots LR (1999) Screening for 21-hydroxylase-deficient nonclassic adrenal hyperplasia among hyperandrogenic women: a prospective study. Fertil Steril 72: 915-925

Balducci R, Boscherini B, Mangiantini A, Morellini M, Toscano V (1994) Isolated precocious pubarche: an approach. J Clin Endocrinol Metab 79: 582-589. doi: 10.1210/jcem.79.2.8045980

Barnes ND, Atherden SM (1972) Diagnosis of congenital adrenal hyperplasia by measurement of plasma 17-hydroxyprogesterone. Arch Dis Child 47: 62-65. doi: 10.1136/adc.47.251.62

Bauland CG, Smit JM, Scheffers SM, Bartels RH, van den Berg P, Zeebregts CJ, Spauwen PH (2012) Similar risk for hemangiomas after amniocentesis and transabdominal chorionic villus sampling. $J$ Obstet Gynaecol Res 38: 371-375. doi: 10.1111/j.1447-0756.2011.01717.x

Benkert AR, Young M, Robinson D, Hendrickson C, Lee PA, Strauss KA (2015) Severe salt-losing 3 $\beta$-hydroxysteroid dehydrogenase deficiency: treatment and outcomes of HSD3B2 c.35G $>$ A Homozygotes. J Clin Endocrinol Metab 100: E1105-E1115. doi: 10.1210/ jc. $2015-2098$

Benn P, Borell A, Chiu R, Cuckle H, Dugoff L, Faas B, Gross S, Johnson J, Maymon R, Norton M, Odibo A, Schielen P, Spencer K, Huang T, Wright D, Yaron Y (2013) Position statement from the aneuploidy screening committee on behalf of the board of the international society for prenatal diagnosis. Prenat Diagn 33: 622629. doi: $10.1002 / \mathrm{pd} .4139$

Bronstad I, Breivik L, Methlie P, Wolff ASB, Bratland E, Nermoen I, Lovas K, Husebye ES (2014) Functional studies of novel CYP21A2 mutations detected in Norwegian patients with congenital adrenal hyperplasia. Endocr Connect 3: 67-74. doi: 10.1530/EC-14-0032

Bulsari K, Falhammar H (2017) Clinical perspectives in congenital adrenal hyperplasia due to $11 \beta$-hydroxylase deficiency. Endocrine 55: 19-36. doi: 10.1007/s12020-016-1189-x

Carlson AD, Obeid JS, Kanellopoulou N, Wilson RC, New MI (1999) Congenital adrenal hyperplasia: update on prenatal diagnosis and treatment. J Steroid Biochem Mol Biol 69: 19-29

Chan CL, McFann K, Taylor L, Wright D, Zeitler PS, Barker JM (2013) Congenital adrenal hyperplasia and the second newborn screen. J Pediatr 163: 109-113. e1. doi: 10.1016/j.jpeds.2013.01.002

Choi J-H, Kim G-H, Yoo H-W (2016) Recent advances in biochemical and molecular analysis of congenital adrenal hyperplasia due to 21-hydroxylase deficiency. Ann Pediatr Endocrinol Metab 21: 1. doi: 10.6065/apem.2016.21.1.1

Clayton PE, Miller WL, Oberfield SE, Ritzén EM, Sippell WG, Speiser PW, ESPE/ LWPES CAH Working Group (2002) Consensus statement on 21-hydroxylase deficiency from the European Society for Paediatric Endocrinology and the Lawson Wilkins Pediatric Endocrine Society. Horm Res 58: 188-195. doi: 65490

Dacou-Voutetakis C, Dracopoulou M (1999) High incidence of molecular defects of the CYP21 gene in patients with premature adrenarche. J Clin Endocrinol Metab 84: 1570-1574. doi: 10.1210/ jcem.84.5.5683

Decourt J, Jayle MF, Baulieu E (1957) Clinically late virilism with excretion of pregnanetriol and insufficiency of cortisol production]. Ann Endocrinol 18: 416-422

DellePiane L, Rinaudo PF, Miller WL (2015) 150 Years of congenital adrenal hyperplasia: translation and commentary of De Crecchio's Classic Paper from 1865. Endocrinology 156: 1210-1217. doi: 10.1210/en.2014-1879

Demirci C, Witchel SF (2008) Congenital adrenal hyperplasia. Dermatol Ther 21: 340-353. doi: 10.1111/j.1529-8019.2008.00216.x

Devers PL, Cronister A, Ormond KE, Facio F, Brasington CK, Flodman P (2013) Noninvasive prenatal testing/noninvasive prenatal diagnosis: the position of the National Society of Genetic Counselors. J Genet Couns 22: 291-295. doi: 10.1007/s10897-012-9564-0

Eugster EA, Dimeglio LA, Wright JC, Freidenberg GR, Seshadri R, Pescovitz OH (2001) Height outcome in congenital adrenal hyperplasia caused by 21-hydroxylase deficiency: a meta-analysis. I Pediatr 138: 26-32. doi: $10.1067 / \mathrm{mpd} .2001 .110527$

Evans MI, Wapner RJ (2005) Invasive prenatal diagnostic procedures 2005. Semin Perinatol 29: 215-218. doi: $10.1053 /$ j.semperi.2005.06.004 Falhammar H, Filipsson H, Holmdahl G, Janson P-O, Nordenskjöld A, Hagenfeldt K, Thorén M (2007) Metabolic profile and body composition in adult women with congenital adrenal hyperplasia due to 21-hydroxylase deficiency. I Clin Endocrinol Metab 92: 110 116. doi: $10.1210 /$ jc.2006-1350

Falhammar H, Filipsson H, Holmdahl G, Janson P-O, Nordenskjöld A, Hagenfeldt K, Thorén M (2013) Bone mineral density, bone markers, and fractures in adult males with congenital adrenal hyperplasia. Eur J Endocrinol 168: 331-341. doi: 10.1530/EJE-12-0865

Falhammar H, Nordenström A (2015) Nonclassic congenital adrenal hyperplasia due to 21-hydroxylase deficiency: clinical presentation, diagnosis, treatment, and outcome. Endocrine 50: 32-50. doi: 10.1007/s12020-015-0656-0

Falhammar H, Wedell A, Nordenström A (2015) Biochemical and genetic diagnosis of 21-hydroxylase deficiency. Endocrine 50: 306-314. doi: 10.1007/s12020-015-0731-6

Ferguson JJ (1963) Protein synthesis and adrenocorticotropin responsiveness. I Biol Chem 238: 2754-2759

Gatelais F, Berthelot J, Beringue F, Descamps P, Bonneau D, Limal J-M, Coutant R (2004) Effect of single and multiple courses of prenatal corticosteroids on 17-hydroxyprogesterone levels: implication for neonatal screening of congenital adrenal hyperplasia. Pediatr Res 56: 701-705. doi: 10.1203/01.PDR.0000142733.50918.6E

Ghayee HK, Auchus RJ (2007) Basic concepts and recent developments in human steroid hormone biosynthesis. Rev Endoor Metab Disord 8: 289-300. doi: 10.1007/s11154-007-9052-2

Gonzalez FJ (1988) The molecular biology of cytochrome P450s. Pharmacol Rev 40: 243-288

Gurian EA, Kinnamon DD, Henry JJ, Waisbren SE (2006) Expanded newborn screening for biochemical disorders: the effect of a falsepositive result. Pediatrics 117: 1915-1921. doi: 10.1542/peds.20052294

Kao PC, Machacek DA, Magera MJ, Lacey JM, Rinaldo P (2001) Diagnosis of adrenal cortical dysfunction by liquid chromatographytandem mass spectrometry. Ann Clin Lab Sci 31: 199-204

Kashimada K, Ono M, Onishi T, Koyama S, Toyoura T, Imai K, Saisho S, Mizutani S (2008) Clinical course of patients with nonclas- 
sical 21-hydroxylase deficiency (21-OHD) diagnosed in infancy and childhood. Endoor J 55: 397-404

Kaur J, Casas L, Bose HS (2016) Lipoid congenital adrenal hyperplasia due to STAR mutations in a Caucasian patient. Endocrinol Diabetes Metab Case Rep 2016: 150119. doi: 10.1530/EDM-15-0119

King JL, Naber JM, Hopkin RJ, Repaske DR, Bailey L, Leslie ND (2001) Antenatal corticosteroids and newborn screening for congenital adrenal hyperplasia. Arch Pediatr Adolesc Med 155: 1038-1042

Knowles RL, Khalid JM, Oerton JM, Hindmarsh PC, Kelnar CJ, Dezateux C (2014) Late clinical presentation of congenital adrenal hyperplasia in older children: findings from national paediatric surveillance. Arch Dis Child 99: 30-34. doi: 10.1136/archdischild-2012-303070

Kohn B, Levine LS, Pollack MS, Pang S, Lorenzen F, Levy D, Lerner AJ, Rondanini GF, Dupont B, New MI (1982) Late-onset steroid 21-hydroxylase deficiency: a variant of classical congenital adrenal hyperplasia. J Clin Endocrinol Metab 55: 817-827. doi: 10.1210/jcem55-5-817

Krone N, Braun A, Roscher AA, Knorr D, Schwarz HP (2000) Predicting phenotype in steroid 21-hydroxylase deficiency? Comprehensive genotyping in 155 unrelated, well defined patients from southern Germany. I Clin Endocrinol Metab 85: 1059-1065. doi: 10.1210/ jcem.85.3.6441

Krone N, Dhir V, Ivison HE, Arlt W (2007) Congenital adrenal hyperplasia and P450 oxidoreductase deficiency. Clin Endocrinol (Oxf) 66: 162-172. doi: 10.1111/j.1365-2265.2006.02740.x

Krone N, Hughes BA, Lavery GG, Stewart PM, Arlt W, Shackleton CHL (2010) Gas chromatography/mass spectrometry (GC/MS) remains a pre-eminent discovery tool in clinical steroid investigations even in the era of fast liquid chromatography tandem mass spectrometry (LC/MS/MS). J Steroid Biochem Mol Biol 121: 496-504. doi: 10.1016/j.jsbmb.2010.04.010

Lander ES, Linton LM, Birren B, Nusbaum C, Zody MC, Baldwin J, Devon K, Dewar K, Doyle, M, FitzHugh W, Funke R, Gage D, Harris K, Heaford A, Howland J, Kann L, Lehoczky J, LeVine R, McEwan P, McKernan K, Meldrim J, Mesirov JP, Miranda C, Morris W, Naylor J, Raymond C, Rosetti M, Santos R, Sheridan A, Sougnez C, Stange-Thomann N, Stojanovic N, Subramanian A, Wyman D, Rogers J, Sulston J, Ainscough R, Beck S, Bentley D, Burton J, Clee C, Carter N, Coulson A, Deadman R, Deloukas P, Dunham A, Dunham I, Durbin R, French L, Grafham D, Gregory S, Hubbard T, Humphray S, Hunt A, Jones M, Lloyd C, McMurray A, Matthews $L$, Mercer S, Milne S, Mullikin JC, Mungall A, Plumb R, Ross M, Shownkeen R, Sims S, Waterston RH, Wilson RK, Hillier LW, McPherson JD, Marra MA, Mardis ER, Fulton LA, Chinwalla AT, Pepin KH, Gish WR, Chissoe SL, Wendl MC, Delehaunty KD, Miner TL, Delehaunty A, Kramer JB, Cook LL, Fulton RS, Johnson DL, Minx PJ, Clifton SW, Hawkins T, Branscomb E, Predki P, Richardson P, Wenning S, Slezak T, Doggett N, Cheng J-F, Olsen A, Lucas S, Elkin C, Uberbacher E, Frazier M, Gibbs RA, Muzny DM, Scherer SE, Bouck JB, Sodergren EJ, Worley KC, Rives CM, Gorrell JH, Metzker ML, Naylor SL, Kucherlapati RS, Nelson DL, Weinstock GM, Sakaki, Y, Fujiyama A, Hattori M, Yada T, Toyoda A, Itoh T, Kawagoe C, Watanabe H, Totoki Y, Taylor T, Weissenbach J, Heilig R, Saurin W, Artiguenave F, Brottier P, Bruls T, Pelletier E, Robert C, Wincker P, Rosenthal A, Platzer M, Nyakatura G, Taudien S, Rump A, Smith DR, DoucetteStamm L, Rubenfield M, Weinstock K, Lee HM, Dubois J, Yang H, Yu J, Wang J, Huang G, Gu J, Hood L, Rowen L, Madan A, Qin S, Davis RW, Federspiel NA, Abola AP, Proctor MJ, Roe BA, Chen F, Pan H, Ramser J, Lehrach H, Reinhardt R, McCombie WR, Bastide $M$ de la, Dedhia N, Blöcker H, Hornischer K, Nordsiek G, Agarwala R, Aravind L, Bailey JA, Bateman A, Batzoglou S, Birney E, Bork P, Brown DG, Burge CB, Cerutti L, Chen H-C, Church D, Clamp M, Copley RR, Doerks T, Eddy SR, Eichler EE, Furey TS, Galagan J, Gilbert JGR, Harmon C, Hayashizaki Y, Haussler D, Hermjakob H, Hokamp K, Jang W, Johnson LS, Jones TA, Kasif S, Kaspryzk A, Kennedy S, Kent WJ, Kitts P, Koonin EV, Korf I, Kulp D, Lancet D, Lowe TM, McLysaght A, Mikkelsen T, Moran JV, Mulder N, Pollara VJ, Ponting CP, Schuler G, Schultz J, Slater G, Smit AFA, Stupka E, Szustakowki J, Thierry-Mieg D, ThierryMieg J, Wagner L, Wallis J, Wheeler R, Williams A, Wolf YI, Wolfe KH, Yang S-P, Yeh R-F, Collins F, Guyer MS, Peterson J, Felsenfeld A, Wetterstrand KA, Myers RM, Schmutz J, Dickson M, Grimwood J, Cox DR, Olson MV, Kaul R, Raymond C, Shimizu N, Kawasaki K, Minoshima S, Evans GA, Athanasiou M, Schultz R, Patrinos A, Morgan MJ (2001) Initial sequencing and analysis of the human genome. Nature 409: 860-921. doi: 10.1038/35057062

Lee MM, Rajagopalan L, Berg GJ, Moshang T (1989) Serum adrenal steroid concentrations in premature infants. I Clin Endocrinol Metab 69: 1133-1136. doi: 10.1210/jcem-69-6-1133

Lin-Su K, Harbison MD, Lekarev O, Vogiatzi MG, New MI (2011) Final adult height in children with congenital adrenal hyperplasia treated with growth hormone. J Clin Endocrinol Metab 96: 17101717. doi: $10.1210 /$ jc.2010-2699
Lo YM, Tein MS, Lau TK, Haines CJ, Leung TN, Poon PM, Wainscoat JS, Johnson PJ, Chang AM, Hjelm NM (1998) Quantitative analysis of fetal DNA in maternal plasma and serum: implications for noninvasive prenatal diagnosis. Am J Hum Genet 62: 768-775. doi: $10.1086 / 301800$

Ma D, Ge H, Li X, Jiang T, Chen F, Zhang Y, Hu P, Chen S, Zhang J, Ji X, Xu X, Jiang H, Chen M, Wang W, Xu Z (2014) Haplotypebased approach for noninvasive prenatal diagnosis of congenital adrenal hyperplasia by maternal plasma DNA sequencing. Gene 544: 252-258. doi: 10.1016/j.gene.2014.04.055

Ma D, Yuan Y, Luo C, Wang Y, Jiang T, Guo F, Zhang J, Chen C, Sun Y, Cheng J, Hu P, Wang J, Yang H, Yi X, Wang W, Asan Xu Z (2017) Noninvasive prenatal diagnosis of 21-Hydroxylase deficiency using target capture sequencing of maternal plasma DNA. Sci Rep 7. doi: 10.1038/s41598-017-06828-2

Marumudi E, Khadgawat R, Surana V, Shabir I, Joseph A, Ammini AC (2013) Diagnosis and management of classical congenital adrenal hyperplasia. Steroids 78: 741-746. doi: 10.1016/j.steroids.2013.04.007

Merke DP, Bornstein SR (2005) Congenital adrenal hyperplasia. The Lancet 365: 2125-2136

Mesiano S, Mellon SH, Gospodarowicz D, Di Blasio AM, Jaffe RB (1991) Basic fibroblast growth factor expression is regulated by corticotropin in the human fetal adrenal: a model for adrenal growth regulation. Proc Natl Acad Sci U S A 88: 5428-5432

Miller WL (2005) Minireview: regulation of steroidogenesis by electron transfer. Endocrinology 146: 2544-2550. doi: 10.1210/en.2005-0096

Miller WL (2012) The syndrome of 17,20 lyase deficiency. J ClinEndocrinolMetab 97:59-67 . doi: 10.1210/jc.2011-2161

Miller WL, Auchus RJ (2011) The molecular biology, biochemistry, and physiology of human steroidogenesis and its disorders. Endocr Rev 32: 81-151. doi: 10.1210/er.2010-0013

Monostori P, Szabó P, Marginean O, Bereczki C, Karg E (2015) Concurrent confirmation and differential diagnosis of congenital adrenal hyperplasia from dried blood spots: application of a second-tier LCMS/MS assay in a cross-border cooperation for newborn screening. Horm Res Paediatr 84: 311-318. doi: 10.1159/000439380

Moran C, Azziz R, Carmina E, Dewailly D, Fruzzetti F, Ibañez L, Knochenhauer ES, Marcondes JA, Mendonca BB, Pignatelli D, Pugeat M, Rohmer V, Speiser PW, Witchel SF (2000) 21-Hydroxylase-deficient nonclassic adrenal hyperplasia is a progressive disorder: a multicenter study. Am J Obstet Gynecol 183: 1468-1474. doi: 10.1067/mob.2000.108020

Nelson DR, Kamataki T, Waxman DJ, Guengerich FP, Estabrook RW, Feyereisen R, Gonzalez FJ, Coon MJ, Gunsalus IC, Gotoh $\mathrm{O}$ (1993) The P450 superfamily: update on new sequences, gene mapping, accession numbers, early trivial names of enzymes, and nomenclature. DNA Cell Biol 12: 1-51. doi: 10.1089/dna.1993.12.1

New MI (2011) Ancient history of congenital adrenal hyperplasia. Endocr Dev 20: 202-211. doi: 10.1159/000321248

New MI (2003) Inborn errors of adrenal steroidogenesis. Mol Cell Endocrinol 211: 75-84. doi: 10.1016/j.mce.2003.09.013

New MI, Abraham M, Gonzalez B, Dumic M, Razzaghy-Azar M, Chitayat D, Sun L, Zaidi M, Wilson RC, Yuen T (2013) Genotypephenotype correlation in 1,507 families with congenital adrenal hyperplasia owing to 21-hydroxylase deficiency. Proc Natl Acad Sci 110: 2611-2616. doi: 10.1073/pnas. 1300057110

New MI, Carlson A, Obeid J, Marshall I, Cabrera MS, Goseco A, LinSu K, Putnam AS, Wei JQ, Wilson RC (2001) Prenatal diagnosis for congenital adrenal hyperplasia in 532 pregnancies. J Clin Endocrinol Metab 86: 5651-5657. doi: 10.1210/jcem.86.12.8072

New MI, Lorenzen F, Lerner AJ, Kohn B, Oberfield SE, Pollack MS, Dupont B, Stoner E, Levy DJ, Pang S, Levine LS (1983) Genotyping steroid 21-hydroxylase deficiency: hormonal reference data. $J$ Clin Endocrinol Metab 57: 320-326. doi: 10.1210/jcem-57-2-320

New MI, Tong YK, Yuen T, Jiang P, Pina C, Chan KCA, Khattab A, Liao GJW, Yau M, Kim S-M, Chiu RWK, Sun L, Zaidi M, Lo YMD (2014) Noninvasive prenatal diagnosis of congenital adrenal hyperplasia using cell-free fetal dna in maternal plasma. J Clin Endocrinol Metab 99: E1022-E1030. doi: 10.1210/jc.2014-1118

Ney RL, Dexter RN, Davis WW, Garren LD (1967) A Study of the Mechanisms by Which Adrenocorticotropic Hormone maintains adrenal steroidogenic responsiveness. J Clin Invest 46: 1916-1924

Nimkarn S, New MI (2009) Prenatal diagnosis and treatment of congenital adrenal hyperplasia due to 21-hydroxylase deficiency. Mol Cell Endocrinol 300: 192-196. doi: 10.1016/j.mce.2008.11.027

Ostlere LS, Rumsby G, Holownia P, Jacobs HS, Rustin MH, Honour JW (1998) Carrier status for steroid 21-hydroxylase deficiency is only one factor in the variable phenotype of acne. Clin Endocrinol (Oxf) 48: 209-215

Pang S, Clark A, Neto EC, Giugliani R, Dean H, Winter J, Dhondt J-L, Farriaux JP, Graters A, Cacciari E (1993) Congenital adrenal hyperplasia due to 21-hydroxylase deficiency: newborn screening and its relationship to the diagnosis and treatment of the disorder. Screening 2: 105-139

Pang S, Hotchkiss J, Drash AL, Levine LS, New MI (1977) Microfilter paper method for 17 alpha-hydroxyprogesterone radioimmunoassay: 
its application for rapid screening for congenital adrenal hyperplasia. J Clin Endocrinol Metab 45: 1003-1008. doi: 10.1210/jcem-45-5-1003

Pang S, Murphey W, Levine LS, Spence DA, Leon A, LaFranchi S, Surve AS, New MI (1982) A pilot newborn screening for congenital adrenal hyperplasia in Alaska. J Clin Endocrinol Metab 55: 413-420. doi: 10.1210/jcem-55-3-413

Pang S, Wallace MA, Hofman L, Thuline HC, Dorche C, Lyon ICT, Dobbins RH, Kling S, Fujieda K, Suwa S (1988) Worldwide experience in newborn screening for classical congenital adrenal hyperplasia due to 21-hydroxylase deficiency. Pediatrics 81: 866-874

Pang SY, Legido A, Levine LS, Temeck JW, New MI (1987) Adrenal androgen response to metyrapone, adrenocorticotropin, and corticotropin-releasing hormone stimulation in children with hypopituitarism. J Clin Endocrinol Metab 65: 282-289. doi: 10.1210/jcem65-2-282

Parsa AA, New MI (2017) Steroid 21-hydroxylase deficiency in congenital adrenal hyperplasia. J Steroid Biochem Mol Biol 165: 2-11. doi: 10.1016/j.jsbmb.2016.06.015

Penning TM (1997) Molecular endocrinology of hydroxysteroid dehydrogenases. Endocr Rev 18: 281-305. doi: 10.1210/edrv.18.3.0302

Pon LA, Hartigan JA, Orme-Johnson NR (1986) Acute ACTH regulation of adrenal corticosteroid biosynthesis. Rapid accumulation of a phosphoprotein. J Biol Chem 261: 13309-13316

Punthakee Z, Legault L, Polychronakos C (2003) Prednisolone in the treatment of adrenal insufficiency: a re-evaluation of relative potency. J Pediatr 143: 402-405. doi: 10.1067/S0022-3476(03)00294-4

Quintos JB, Vogiatzi MG, Harbison MD, New MI (2001) Growth hormone therapy alone or in combination with gonadotropin-releasing hormone analog therapy to improve the height deficit in children with congenital adrenal hyperplasia. J Clin Endocrinol Metab 86: 1511-1517. doi: 10.1210/jcem.86.4.7412

Reisch N, Kuhnle U (2014) Geographical Endocrinology of Genetic Steroid Disorders. In Genetic Steroid Disorders. Elsevier, pp 351-356

Rivkees SA, Crawford JD (2000) Dexamethasone treatment of virilizing congenital adrenal hyperplasia: the ability to achieve normal growth. Pediatrics 106: 767-773

Shackleton CH (1986) Profiling steroid hormones and urinary steroids. J Chromatogr 379: 91-156

Speiser PW (2009) Nonclassic adrenal hyperplasia. Rev Endocr Metab Disord 10: 77-82. doi: 10.1007/s11154-008-9097-x

Speiser PW, Azziz R, Baskin LS, Ghizzoni L, Hensle TW, Merke DP, Meyer-Bahlburg HFL, Miller WL, Montori VM, Oberfield SE, Ritzen M, White PC, Endocrine Society (2010) Congenital adrenal hyperplasia due to steroid 21-hydroxylase deficiency: an Endocrine Society clinical practice guideline. J Clin Endocrinol Metab 95: 41334160. doi: 10.1210/jc.2009-2631

Speiser PW, Dupont J, Zhu D, Serrat J, Buegeleisen M, Tusie-Luna MT, Lesser M, New MI, White PC (1992) Disease expression and molecular genotype in congenital adrenal hyperplasia due to 21-hydroxylase deficiency. J Clin Invest 90: 584-595. doi: 10.1172/ JCI115897

Speiser PW, White PC (2003a) Congenital adrenal hyperplasia. N Engl J Med 349: 776-788. doi: 10.1056/NEJMra021561

Speiser PW, White PC (2003b) Congenital adrenal hyperplasia. N Engl J Med 349: 776-788

Stoner E, Dimartino-Nardi J, Kuhnle U, Levine LS, Oberfield SE, New MI (1986) Is salt-wasting in congenital adrenal hyperplasia due to the same gene as the fasciculata defect? Clin Endocrinol (Oxf) 24: $9-20$

Temeck JW, Pang S, Nelson C, New MI (1987) Genetic defects of steroidogenesis in premature pubarche. J Clin Endocrinol Metab 64: 609-617. doi: 10.1210/jcem-64-3-609

Therrell BL, Adams J (2007) Newborn screening in North America. J Inherit Metab Dis 30: 447-465. doi: 10.1007/s10545-007-0690-z

Therrell BL, Berenbaum SA, Manter-Kapanke V, Simmank J, Korman K, Prentice L, Gonzalez J, Gunn S (1998) Results of screening 1.9 million Texas newborns for 21-hydroxylase-deficient congenital adrenal hyperplasia. Pediatrics 101: 583-590. doi: 10.1542/ peds.101.4.583

Trapp CM, Speiser PW, Oberfield SE (2011) Congenital adrenal hyperplasia: an update in children. Curr Opin Endocrinol Diabetes Obes 18: 166-170. doi: 10.1097/MED.0b013e328346938c

Van der Kamp HJ, Noordam K, Elvers B, Van Baarle M, Otten BJ, Verkerk PH (2001) Newborn screening for congenital adrenal hyperplasia in the Netherlands. Pediatrics 108: 1320-1324

Venter JC, Adams MD, Myers EW, Li PW, Mural RJ, Sutton GG, Smith HO, Yandell M, Evans CA, Holt RA, Gocayne JD, Amana- tides P, Ballew RM, Huson DH, Wortman JR, Zhang Q, Kodira CD, Zheng XH, Chen L, Skupski M, Subramanian G, Thomas PD, Zhang J, Miklos GLG, Nelson C, Broder S, Clark AG, Nadeau J, McKusick VA, Zinder N, Levine AJ, Roberts RJ, Simon M, Slayman C, Hunkapiller M, Bolanos R, Delcher A, Dew I, Fasulo D, Flanigan M, Florea L, Halpern A, Hannenhalli S, Kravitz S, Levy S, Mobarry C, Reinert K, Remington K, Abu-Threideh J, Beasley E, Biddick K, Bonazzi V, Brandon R, Cargill M, Chandramouliswaran I, Charlab R, Chaturvedi K, Deng Z, Francesco VD, Dunn P, Eilbeck K, Evangelista C, Gabrielian AE, Gan W, Ge W, Gong F, Gu Z, Guan P, Heiman TJ, Higgins ME, Ji R-R, Ke Z, Ketchum KA, Lai Z, Lei Y, Li Z, Li J, Liang Y, Lin X, Lu F, Merkulov GV, Milshina N, Moore HM, Naik AK, Narayan VA, Neelam B, Nusskern D, Rusch DB, Salzberg S, Shao W, Shue B, Sun J, Wang ZY, Wang A, Wang X, Wang J, Wei M-H, Wides R, Xiao C, Yan C, Yao A, Ye J, Zhan M, Zhang W, Zhang H, Zhao Q, Zheng L, Zhong F, Zhong W, Zhu SC, Zhao S, Gilbert D, Baumhueter S, Spier G, Carter C, Cravchik A, Woodage T, Ali F, An H, Awe A, Baldwin D, Baden H, Barnstead M, Barrow I, Beeson K, Busam D, Carver A, Center A, Cheng ML, Curry L, Danaher S, Davenport L, Desilets R, Dietz S, Dodson K, Doup L, Ferriera S, Garg N, Gluecksmann A, Hart B, Haynes J, Haynes C, Heiner C, Hladun S, Hostin D, Houck J, Howland T, Ibegwam C, Johnson J, Kalush F, Kline L, Koduru S, Love A, Mann F, May D, McCawley S, McIntosh T, McMullen I, Moy M, Moy L, Murphy B, Nelson K, Pfannkoch C, Pratts E, Puri V, Qureshi H, Reardon M, Rodriguez R, Rogers Y-H, Romblad D, Ruhfel B, Scott R, Sitter C, Smallwood M, Stewart E, Strong R, Suh E, Thomas R, Tint NN, Tse S, Vech C, Wang G, Wetter J, Williams S, Williams M, Windsor S, WinnDeen E, Wolfe K, Zaveri J, Zaveri K, Abril JF, Guigó R, Campbell MJ, Sjolander KV, Karlak B, Kejariwal A, Mi H, Lazareva B, Hatton T, Narechania A, Diemer K, Muruganujan A, Guo N, Sato S, Bafna V, Istrail S, Lippert R, Schwartz R, Walenz B, Yooseph S, Allen D, Basu A, Baxendale J, Blick L, Caminha M, Carnes-Stine J, Caulk P, Chiang Y-H, Coyne M, Dahlke C, Mays AD, Dombroski M, Donnelly M, Ely D, Esparham S, Fosler C, Gire H, Glanowski S, Glasser K, Glodek A, Gorokhov M, Graham K, Gropman B, Harris M, Heil J, Henderson S, Hoover J, Jennings D, Jordan C, Jordan J, Kasha J, Kagan L, Kraft C, Levitsky A, Lewis M, Liu X, Lopez J, Ma D, Majoros W, McDaniel J, Murphy S, Newman M, Nguyen T, Nguyen N, Nodell M, Pan S, Peck J, Peterson M, Rowe W, Sanders R, Scott J, Simpson M, Smith T, Sprague A, Stockwell $\mathrm{T}$, Turner R, Venter E, Wang M, Wen M, Wu D, Wu M, Xia A, Zandieh A, Zhu X (2001) The sequence of the human genome. Science 291: 1304-1351. doi: 10.1126/science. 1058040

Verma S, Vanryzin C, Sinaii N, Kim MS, Nieman LK, Ravindran S, Calis KA, Arlt W, Ross RJ, Merke DP (2010) A pharmacokinetic and pharmacodynamic study of delayed- and extended-release hydrocortisone (Chronocort) vs. conventional hydrocortisone (Cortef) in the treatment of congenital adrenal hyperplasia. Clin Endocrinol (Oxf) 72: 441-447. doi: 10.1111/j.1365-2265.2009.03636.x

Voutilainen R, Jääskeläinen J (2015) Premature adrenarche: etiology, clinical findings, and consequences. I Steroid Biochem Mol Biol 145: 226-236. doi: 10.1016/j.jsbmb.2014.06.004

Wedell A, Thilén A, Ritzén EM, Stengler B, Luthman H (1994) Mutational spectrum of the steroid 21-hydroxylase gene in Sweden: implications for genetic diagnosis and association with disease manifestation. J Clin Endocrinol Metab 78: 1145-1152. doi: 10.1210/ jcem.78.5.8175971

White PC (2009) Neonatal screening for congenital adrenal hyperplasia. Nat Rev Endocrinol 5: 490-498. doi: 10.1038/nrendo.2009.148

Witchel SF (2017) Congenital adrenal hyperplasia. J Pediatr Adolesc Gynecol 30:520-534. doi: 10.1016/j.jpag.2017.04.001

Witchel SF (2010) The medical home concept and congenital adrenal hyperplasia: a comfortable habitat! Int J Pediatr Endocrinol 2010: 561526. doi: 10.1155/2010/561526

Wong T, Shackleton CH, Covey TR, Ellis G (1992) Identification of the steroids in neonatal plasma that interfere with 17 alpha-hydroxyprogesteroneradioimmunoassays. Clin Chem 38: 1830-1837

Yau M, Khattab A, New MI (2016a) Prenatal diagnosis of congenital adrenal hyperplasia. Endocrinol Metab Clin North Am 45: 267-281. doi: 10.1016/j.ecl.2016.01.001

Yau M, Nimkarn S, New MI (2016b) Congenital Adrenal Hyperplasia. In Genetic Diagnosis of Endocrine Disorders, pp 203-210. Elsevier 